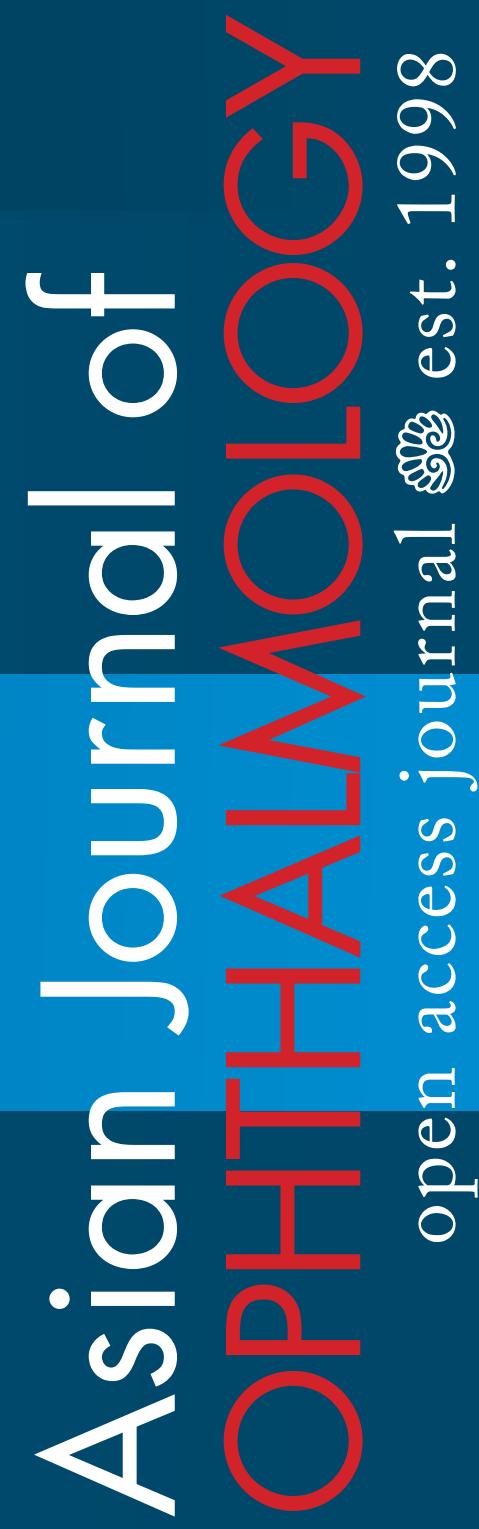

Volume $13 \cdot$ Issue $4 \cdot 2014 \cdot 1560-2133$ 


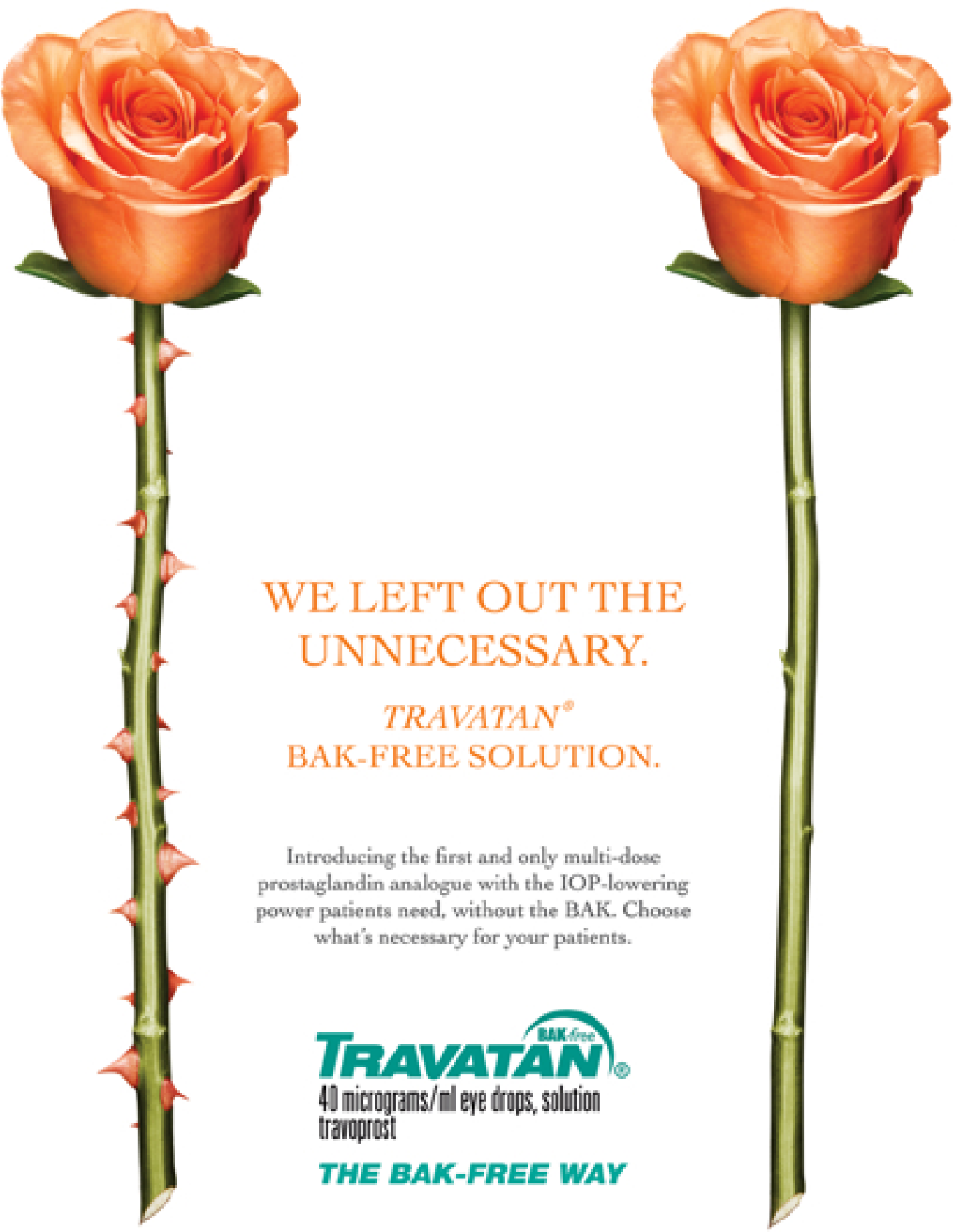

For more information on the product please contact your local Alcon' representative 


\section{Asian Journal of OPHTHALMOLOGY}

Submit your article now to the

Asian Journal of

a peer-reviewed online open access journal.

There are no publication costs, hidden fees or charges.

\section{Chief editor: Paul Chew}

The objectives of Asian Journal of Ophthalmology are as follows:

- To provide a platform for the publication of information with a focus on Ophthalmology in Asia

- To disseminate information that will improve the care of patients with all types of ophthalmological disorders, with a special focus on glaucoma

- To increase the understanding of such disorders through reporting of educational activities

- To publish the results of research programmes to expand knowledge about the causes, prevention, and treatment of ophthalmological disorders

- To work closely with Asian and international researchers to achieve these aims

- To provide a forum for young and relatively inexperienced researchers to present their research results as Original Articles via an international platform

- To maintain and promote relationships with any organisation with similar goals.

For more information, an article template and submission guidelines, see www.asjoo.com

PUBLICATION SCHEDULE 2014-2015:

2014

September 2014

September 2014

October 2014

December 2014

14-1

Highlights print issue

(APGC)

14-2

14-3
2015

February $2015 \quad$ 14-4: Special issue on

Generic Medications

April 2015

July 2015

October 2015

January 2016
15-1

15-2

15-3

15-4

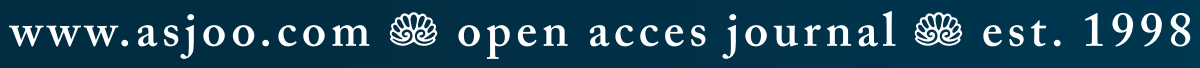




\title{
Diagnostic value of contrast sensitivity test and conjunctival impression cytology for the detection of sub-clinical vitamin-a deficiency
}

\author{
T.D. Gondhowiardjo, ${ }^{1,2}$ I. Andriyani, ${ }^{1,2}$ S. Gumay, ${ }^{3}$ W. Artini, ${ }^{1,2}$ \\ R.A. Werdhana ${ }^{4}$ \\ 'Department of Ophthalmology, Faculty of Medicine; ${ }^{2}$ Department of \\ Ophthalmology, Cipto Mangunkusumo National Hospital; ${ }^{3}$ Department of \\ Anatomical Pathology, Faculty of Medicine; ${ }^{4}$ Department of Community Medicine, \\ Faculty of Medicine, University of Indonesia, Jakarta, Indonesia
}

\begin{abstract}
Purpose: To determine whether or not contrast sensitivity test and conjunctival impression cytology can be used as diagnostic tools to detect sub-clinical vitamin-A deficiency; and if there is a correlation within the two diagnostic methods.

Methods: A series of diagnostic studies comprising of contrast sensitivity test, conjunctival impression examination and serum retinol concentration were performed on literate children, six to ten years old, at West Java Elementary School. All subjects underwent a basic eye examination. Sample size, receiver operator curve, negative and positive predictive values, sensitivity and specificity were calculated.

Results: A total of 109 subjects out of 154 elementary school children corresponding to the inclusion criteria were included in this study. Forty-four (41.9\%) children were detected to have sub-clinical vitamin-A deficiency. The contrast sensitivity test had a sensitivity value of $45.5 \%$ and a specificity value of $50.8 \%$ with a positive predictive value of $40 \%$. The area under the receiver operator characteristic (ROC) curve was $49.5 \%$ (95\% Cl 38.1\%$60.9 \%)$, whereas the conjunctival impression cytology test had a sensitivity value of $90.9 \%$, and a specificity value of $16.4 \%$ with a positive predictive value of $43.9 \%$. The ROC area was $56.1 \%$ (95\% Cl $45.0 \%$ - 67.1\%). Pearson's analysis showed that there is no correlation between the two diagnostic tools ( $p$ 0.538).

Conclusion: The results of this study indicated that neither the contrast sensitivity test nor the conjunctival impression cytology was found to be a favorable screening tool to detect sub-clinical vitamin-A deficiency. Moreover, there is no correlation between the two methods.
\end{abstract}

Key words: Sub-clinical vitamin-A deficiency, contrast sensitivity, impression cytology

\section{Introduction}

Vitamin-A deficiency is a state or condition resulting from a lack of vitamin-A concentration level in the body tissue, causing either sub-clinical or clinical disorders, including the eyes. ${ }^{1}$ Vitamin-A deficiency currently remains a public health problem worldwide, especially in developing countries, such as Africa and South-East Asia, affecting predominantly the young children during their period of growth. ${ }^{2}$

Correspondence: Gondhowiardjo Tjahjono, Department of Ophthalmology, Cipto Mangunkusumo National Hospital - Faculty of Medicine, University of Indonesia, Jl Kimia 8, Jakarta Pusat, Indonesia. E-mail: tgondh@yahoo.com 
Starting as a silent threat, then later pursuing a pathological course, Vitamin-A deficiency is purported to be the cause of vision loss, especially in children, if not properly and timely managed and treated. In its early stages, it will cause difficulties in seeing in low-light settings, producing a condition known as night blindness. Treated inadequately, the condition will further progress to form abnormalities on the conjunctiva, and later on the cornea, generating a condition known as xerophthalmia, causing permanent damage in the cornea as well as loss of vision. ${ }^{2,3}$

The predicament of vitamin-A deficiency is a perfect example of an iceberg phenomenon where, to date, only a few xerophthalmia cases have been established despite extensive sub-clinical vitamin-A deficiency found in the community. The ratio of sub-clinical vitamin-A deficiency to xerophthalmic patients is ten to one. ${ }^{3-5}$ Sub-clinical vitamin-A deficiency is defined as serum retinol concentration below $20 \mu \mathrm{g} / \mathrm{dl}$ (biochemical indicator), which serves as the gold standard, however, this measurement is an invasive, highly-skilled and costly procedure.

Early detection of sub-clinical vitamin-A deficiency is made possible by performing conjunctival impression cytology. This is an objective, less invasive, simple test performed using bio-pore membrane paper to identify the metaplastic changes of conjunctival surface epithelial found in sub-clinical vitamin-A deficiency. ${ }^{6-10}$

A contrast sensitivity test may be performed in a setting of regular lighting to detect any changes of vision quality despite normal visual acuity. ${ }^{12,13}$ This test is considered simple and reliable, making it a practical tool for early diagnostics.

In this study, we postulated that the contrast sensitivity test as well as the conjunctival impression cytology test prove to be an effective screening tool. The purpose of this study was to acknowledge the diagnostic value of the contrast sensitivity test and conjunctival impression cytology test in the detection of sub-clinical vitamin-A deficiency. We also aimed to compare the value of both tests as a potential tool for screening.

\section{Methods}

This diagnostic study was performed in the Elementary School of Plered Sub-district, Purwakarta, West Java, Indonesia by the School Health Unit - Community Eye Health Service in Cikampek. Thirty elementary schools were randomized and only one school was chosen. Another school was later selected, due to the insufficient number of subjects. The authors obtained prior approval for the study protocol by the Ethics Committee of the Faculty of Medicine University of Indonesia. Written informed consent was obtained from all subjects before recruitment.

Included in this study were literate subjects, six to ten years old, presenting with a visual acuity of $6 / 6$ with maximal spectacle correction of 1.0 Dioptri and showing no abnormalities in the anterior and posterior segments, and who were willing to accept all research procedures.

All subjects underwent the contrast sensitivity examination using Pelli-Robson card with a range illumination of $60-120 \mathrm{~cd} / \mathrm{m}^{2} .^{14}$ This was followed by a conjunctival impression cytology which was done after administration of anesthesia eye drops in both eyes. A conjunctival swab was taken with acetate cellulose paper (HA, 
HA WP 04700, Millipore Corp, Bedford, MA, USA) and manipulated with an objective glass to extract the epithelial cell. The cellulose paper was then placed into a Petri dish containing fixating solution; alcohol $70 \%$, formaldehyde $37 \%$ and acetate glacial acid (20:1:1). The fixated conjunctival samples for the impression cytology evaluation were transferred immediately after collection. The abnormal goblet cells were assessed using PAS and Papanicolaou staining. The staining procedure was conducted by a pathology expert, who was oblivious of the two previous assessment results. Density metaplasia goblet cell $/ \mathrm{mm}^{2}$ was calculated using Tseng criteria. ${ }^{10}$

The venous blood was drawn to quantification of serum retinol concentration using high performance liquid chromatography (HPLC) which was performed in the SEAMO-TROPMED (South East Asia Malnutrition Tropical Medicine) Laboratory, Jakarta.

\section{Operational definition}

The contrast sensitivity test is an assessment of the subject's ability to see and read letters on various gradations of contrast between characters and background under constant illumination. When the contrast sensitivity test was found to be less than $1.75 \mathrm{log}$ unit, it was termed as abnormal. The ability to accurately read more than $1.75 \mathrm{log}$ unit was defined as normal.

Sub-clinical vitamin-A deficiency was defined when serum retinol concentration was within the range of $0.35-0.70 \mu \mathrm{mol} / \mathrm{l}$ or $10-20 \mu \mathrm{g}$, whereas serum retinol concentration of higher than $0.70 \mu \mathrm{mol} / \mathrm{l}$ was defined as normal.

The interpretation of conjunctival impression cytology as grades 2, 3, 4, 5 was classified as abnormal, whereas grades 0 and 1 were considered a normal result.

Nutritional status was determined using the Growth Health Card for Elementary School Children issued by the Indonesian Ministry of Health. This chart is adopted from the Growth Reference Data for children aged between five and 19 years, World Health Organization 2007, which determines the nutritional status of elementary school children, based on gender, age and body-mass index. This chart categorizes the subjects into obese, normal and thin.

\section{Statistical analysis}

The collected data was analyzed using computerized SPSS 16 program. Sample size was calculated by expected sensitivity of both tests of $90 \%$ with an expected false value of $15 \%$. Eighty-eight children altogether were enrolled. We calculated point estimates of predictive value, sensitivity and specificity, as well as the receiver operating curve of contrast sensitivity test and conjunctival impression cytology in detecting sub-clinical vitamin-A deficiency; this was compared to the gold standard, serum retinol concentration. Correlation between the two tests was assessed using Pearson's test. 


\section{Results}

A total of $109(70.8 \%)$ literate children out of 154 elementary school children were included in the study and underwent contrast sensitivity test, conjunctival impression cytology and blood test over a period from March to April 2009. One subject was excluded due to unsuccessful attempts to obtain venous blood. Three subjects were considered as excluded for inconclusive results of the conjunctival impression cytology; thus 105 subjects were considered favorable candidates for this study.

There were 46 (43.8\%) female subjects participating in this study, the average age of subjects being eight years old. Ninety-one (86.7\%) subjects were classified to have normal nutritional status. The prevalence of sub-clinical vitamin-A deficiency was found to be $41.9 \%$ (44/105), suffered equally by male and female subjects. Thirty-four $(77.27 \%)$ subjects detected with decreased level of serum retinol concentration were determined as having a normal nutritional status (Table 1).

Table 1 Characteristic of subjects

\begin{tabular}{|c|l|l|}
\hline Gender & Total & Percentage (\%) \\
\hline Male & & \\
\hline Female & 59 & $56.2 \%$ \\
\hline Age (years) & 46 & $43.8 \%$ \\
\hline $\mathbf{6}$ & & \\
\hline $\mathbf{7}$ & 2 & $1.9 \%$ \\
\hline $\mathbf{8}$ & 15 & $14.3 \%$ \\
\hline $\mathbf{9}$ & 44 & $41.9 \%$ \\
\hline $\mathbf{1 0}$ & 30 & $28.6 \%$ \\
\hline Nutritional Status & 14 & $13.3 \%$ \\
\hline Obese & & \\
\hline Normal & 2 & $1.9 \%$ \\
\hline Thin & 91 & $86.7 \%$ \\
\hline & 12 & $11.4 \%$ \\
\hline $\begin{array}{l}\text { Sub-clinical vitamin } \\
\text { A deficiency }\end{array}$ & 44 & \\
\hline
\end{tabular}




\section{Contrast Sensitivity test}

There were $50(47,6 \%)$ subjects who demonstrated an abnormal ability during the contrast sensitivity test, with an average serum vitamin-A level of $0,83 \pm 0,034 \mu \mathrm{mol} / \mathrm{l}$ $($ mean $\pm S D)$. However, the normal contrast sensitivity group showed a similar level of serum vitamin A. In order to prove whether contrast sensitivity test can be used as a diagnostic tool to detect sub-clinical vitamin-A deficiency in school children, it was necessary to conduct several statistical tests.

The sensitivity value is described as the ability of a diagnostic tool to detect a disease. Data showed that the contrast sensitivity test could only detect $45.5 \%$ of the subjects who presented with sub-clinical vitamin-A deficiency, whereas the specificity of the contrast sensitivity test to rule out subjects with sub-clinical vitamin-A deficiency is $50.8 \%$ (Table 2 ).

The positive predictive value (PPV) of the contrast sensitivity test was $40 \%$, showing that there was a $40 \%$ probability of a subject indicating a positive result to actually have sub-clinical vitamin-A deficiency. Whereas the probability of not having the disease was derived from the negative predictive value (NPV), which is $56.4 \%$.

Furthermore, receiver operator characteristic (ROC) analysis revealed that the ROC curve seems to be too close to the diagonal reference line - the area under curve $49.5 \%$ ( $95 \% \mathrm{Cl} 38.1 \%-60.9 \%)$. If the cut-off point of the contrast sensitivity test is decreased into $\leq 1.57 \log$ unit, the specificity of the test will be raised to $100 \%$, however, its sensitivity will be down to $4.5 \%$. These results demonstrate that the contrast sensitivity test is not an accurate tool in detecting sub-clinical vitamin-A deficiency.

Table 2 Diagnostic value of Contrast Sensitivity test

\begin{tabular}{|r|l|l|l|}
\hline \multirow{2}{*}{ Contrast Sensitivity } & \multicolumn{2}{|l|}{ Serum Retinol Level } & \\
\cline { 2 - 4 } & $(0.35-0.70 \mu \mathrm{mol} / \mathrm{l})$ & $(>0.70 \mu \mathrm{mol} / \mathrm{l})$ & Total \\
\hline Abnormal & $\mathbf{2 0}(\mathrm{a})$ & $\mathbf{3 0}(\mathrm{b})$ & $50(\mathrm{a}+\mathrm{b})$ \\
Normal & $\mathbf{2 4}(\mathrm{c})$ & $\mathbf{3 1}(\mathrm{d})$ & $55(\mathrm{c}+\mathrm{d})$ \\
\hline Total & $44(\mathrm{a}+\mathrm{c})$ & $61(\mathrm{~b}+\mathrm{d})$ & 105 \\
\hline
\end{tabular}

The sensitivity value is $a /(a+c)=20 / 44=45.5 \%$; whereas the specificity yield from $d /(b+d)=31 / 61$ $=50.8 \%$. The PPV was derived from $a /(a+b)=20 / 50=40 \%$, whereas the NPV is $d /(c+d)=31 / 55=$ $56.4 \%$.

\section{Conjunctival impression cytology}

Conjunctival impression cytology is a minimally invasive pathological assessment to detect any pathological changes within the conjunctival surface. There was only 1 (0.9\%) subject who showed grade-2 abnormality and a total of $90(85.7 \%)$ subjects presented with grade- 4 and grade- 5 abnormality of conjunctival impression cytology. Fourteen (13.3\%) subjects were classified to have normal pattern (grade 1). The mean serum retinol concentration of subjects with abnormal conjunctival impression 
cytology was $0.82 \pm 0.029 \mu \mathrm{mol} / \mathrm{l}$. Subjects with normal conjunctival impression cytology showed a mean serum retinol concentration of $0.98 \pm 0.035 \mu \mathrm{mol} / \mathrm{l}$. The difference of serum retinol concentration between subjects with abnormal and normal conjunctival impression cytology was statistically significant ( $p: 0.036)$.
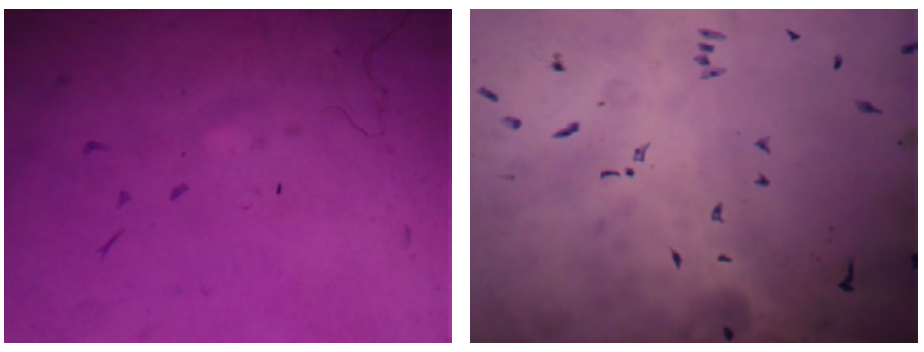

Fig. 1. Grade 4 and 5 conjunctival impression cytology abnormality, showing pycnotic nucleus and un-nucleated basophilic cells on sample no. 13 and 16.

The sensitivity value for conjunctival impression cytology was $90.9 \%$, indicating therefore that this diagnostic tool demonstrated a $90.9 \%$ chance of detecting sub-clinical vitamin-A deficiency. The specificity value was $16.4 \%$, which meant the probability of this test showing a negative result on a healthy subject was $16.4 \%$. The positive predictive value (PPV) for conjunctival impression cytology was $43.9 \%$, showing that there was $43.9 \%$ probability of a subject with a positive test result to actually have sub-clinical vitamin-A deficiency. The probability of a subject with negative result (normal conjunctival impression cytology) for not having the disease was $71.4 \%$ (negative predictive value/NPV)(Table 3).

Table 3 Diagnostic value of conjunctival impression cytology

\begin{tabular}{|l|l|l|l|}
\hline \multirow{2}{*}{$\begin{array}{l}\text { Impression } \\
\text { Cytology }\end{array}$} & \multicolumn{2}{|l|}{ Serum Retinol Level } & \\
\cline { 2 - 4 } & $(0.35-0.70 \mu \mathrm{mol} / \mathrm{l})$ & $(>0.70 \mu \mathrm{mol} / \mathrm{l})$ & Total \\
\hline $\begin{array}{r}\text { Abnormal (> grade 2) } \\
\text { Normal }\end{array}$ & $\begin{array}{l}\mathbf{4 0}(\mathrm{a}) \\
\mathbf{4}(\mathrm{c})\end{array}$ & $\begin{array}{l}\mathbf{5 1}(\mathrm{b}) \\
\mathbf{1 0}(\mathrm{d})\end{array}$ & $\begin{array}{l}91(\mathrm{a}+\mathrm{b}) \\
14(\mathrm{c}+\mathrm{d})\end{array}$ \\
\hline Total & $44(\mathrm{a}+\mathrm{c})$ & $61(\mathrm{~b}+\mathrm{d})$ & 105 \\
\hline
\end{tabular}

The sensitivity and specificity were $90.9 \%$ and $16.4 \%$, respectively; whereas the PPV and the NPV were $43.9 \%$, and $71.4 \%$, respectively.

Receiver operator characteristic (ROC) curve showed the correlation between sensitivity and specificity of conjunctival impression cytology to be a favorable diagnostic tool. The aim was to find the cut-off point of a diagnostic study. Area below ROC was $56.1 \%$ (95\% Cl $45.0 \%-67.1 \%)$. Further analysis revealed that the most appropriate trade-off balance was $56.8 \%$ vs $52.5 \%$, for sensitivity and sensitivity values, respectively, and $46.3 \%$ vs $62.7 \%$ for PPV and NPV, respectively, was achieved by using the grade- 5 pathology of the conjunctival surface as the cut-off point. However, these results still indicate that conjunctival impression cytology is not sufficient enough to be used as an effective diagnostic tool. 


\section{Discussion}

This study revealed that $44(41.9 \%)$ out of 105 subjects were found to have sub-clinical vitamin-A deficiency. Surprisingly, 34 (77.27\%) of them were actually grouped in the 'normal' nutritional status. This finding was in agreement with the fact that sub-clinical vitamin-A deficiency has no clinical manifestations other than the finding of serum retinol concentration is less than $20 \mathrm{gr} / \mathrm{dl} .{ }^{15,16}$ This condition is also known as micronutrient deficiency or hidden hunger. People with this condition are usually unaware of the deficiency experienced by their body. These micronutrients are needed in small amounts only but are truly essential for general health, especially for the eyes. ${ }^{17,18}$

Subjects aged six to ten years were selected to participate in this study, since these particular age groups are not covered by the Indonesian Ministry of Health's vitamin A supplementation program, employed in February and August annually. This program only covers pre-school children under five years old. ${ }^{19}$ This study showed that the majority of sub-clinical vitamin-A deficiency subjects are eight years old, without gender disparities. These results correspond with those of our previous studies. ${ }^{20,21}$

The serum retinol concentration of $0.35-0.70 \mu \mathrm{mol} / \mathrm{l}$, used as an indicator for diagnosing sub-clinical vitamin-A deficiency, does not provide an exact reflection of the total amount of body retinol stored in the liver. It represents only a borderline level between vitamin-A deficiency and normal serum level. ${ }^{22,23} \mathrm{~A}$ stable serum retinol level can be achieved when the liver storage level is very low. ${ }^{23}$

High prevalence of sub-clinical vitamin-A deficiency in children in this study indicated the dietary intake situation in the area. As the nutritional status might hold a role in this finding, considering the high number of children who are undernourished in Plered sub-district, West Java. ${ }^{24}$ Dietary habits of the children in this area constitute one of the factors, since this study was conducted in the mountain and plantation areas, where it is difficult for the people to find animal sources of vitamin A, such as meat, milk, fish, liver and eggs. Low social economy status might also contribute to this predicament. The level of vitamin $A$ in the body is also influenced by respiratory tract infection, persistent diarrhea, anemia, and middle ear infection, frequent afflictions suffered by these children. ${ }^{25,26}$

Detecting the manifestations of sub-clinical vitamin-A deficiency is a challenging task, considering night blindness is the early subjective symptom and more often than not unnoticed by patient. Decreased ability to see in low light intensity is caused by disturbance in the rhodopsin regeneration cycle, subsequently resulting in lower level of contrast sensitivity, which, clinically, can be assessed by contrast sensitivity test. Patients might have visual acuity of $6 / 6$ while experiencing difficulties to see at night. ${ }^{27}$

This study found that the average value of the $50(47.6 \%)$ subjects with abnormal contrast sensitivity is $1.64 \log$ unit, whereas the normal value is $1.75 \log$ unit. Moreover, the mean serum retinol concentration is $0,83 \pm 0,034 \mu \mathrm{mol} / \mathrm{l}$ in both normal and abnormal contrast sensitivity subjects, resulting in the low sensitivity and specificity values. However, this finding was quite different from that of 
Sekarsari ${ }^{21}$ who found the sensitivity of $100 \%$ and specificity of $80.5 \%$ based on the school children population with a mean of abnormal contrast sensitivity value of $1.52 \mathrm{log}$ unit, and an average of serum retinol level of $0.63 \mu \mathrm{mol} / \mathrm{l}$. Similar results were also found by Handayani. ${ }^{28}$ These facts might suggest that the contrast sensitivity test appears to be successful as a diagnostic tool only in the more advance serum retinol level depletion.

Since our finding of low sensitivity values together with the low PPV for contrast sensitivity test indicated that this test is unfavorable as a screening tool in the detection of deficiency of vitamin A, since it revealed only a $40 \%$ probability of a subject with positive test result to actually have sub-clinical vitamin-A deficiency. Several factors contribute to this result; background lighting, light reflection, distance, and personal factors pertaining to the subject. The drawback of this study was that no measurement was taken on room illumination during the test. Moreover, the contrast sensitivity test is a subjective test and might contribute to the variation of its diagnostic values found in our last studies. Fear and shyness in our subjects might also have affected the test results. Measurement bias was avoided by taking a repeated test up to two to three times.

This study showed a total of 91 subjects (86.7\%) with abnormal conjunctival impression cytology, which is higher than the previous study by Rostami et al. ${ }^{26}$ who only revealed $23.6 \%$ prevalence of abnormal conjunctival impression cytology among two to five-year-old children in Teheran. Reddy ${ }^{8}$ reported that $70.5 \%$ out of 246 children aged six to ten years, had serum retinol concentration which is lower than $0.7 \mu \mathrm{mol} / \mathrm{l}$, whereas $85 \%$ of them were found to have an abnormal profile. The prevalence was raised to $97 \%$ in the pre-school children (one to five years old). Moreover, $65 \%$ amongst those who presented with normal conjunctival impression cytology were found to have low serum retinol concentration; which was in contrast to our finding, incorporating only $4(28.6 \%)$ subjects.

Incongruence found in our study between conjunctival impression cytology and serum retinol concentration was most likely due to a poor cytology sample collection process, inadequate amount of serum, poor reagent quality or other unknown contributing factors. ${ }^{22}$ The disadvantage of conjunctival impression cytology as a diagnostic tool was the necessity of optimal cooperation between researcher and the subjects. Uncooperative subjects, especially the children, served to hamper sample collection process, thus affecting the end result. Conjunctival impression cytology also presented its own extent of subjectivity. ${ }^{28}$

The contrast sensitivity test is a functional clinical indicator, whereas the conjunctival impression cytology is a tissue pathological indicator. Further comparability analysis using Pearson's test was not in total accordance and no correlation ( $p$ 0.538 ) was found between the contrast sensitivity test and the conjunctival impression cytology (Table 4). This finding may indicate that there are different kinds of vitamin-A metabolism within the two tissues. 
In conclusion, the results obtained did not support our postulation that either the contrast sensitivity test or the conjunctival impression cytology can be used as a favorable diagnostic screening tool to detect sub-clinical vitamin-A deficiency.

Table 4 Comparability between conjunctival impression cytology and contrast sensitivity test.

\begin{tabular}{|r|l|l|l|}
\hline \multirow{2}{*}{$\begin{array}{l}\text { Contrast } \\
\text { Sensitivity }\end{array}$} & \multicolumn{2}{|l|}{ Impression Cytology } & \\
\cline { 2 - 4 } & Abnormal & Normal & Total \\
\hline $\begin{array}{r}\text { Abnormal } \\
\text { Normal }\end{array}$ & $\mathbf{4 4}(\mathbf{a})$ & $\mathbf{6}(\mathrm{c})$ & $50(\mathrm{a}+\mathrm{b})$ \\
$\mathbf{8}(\mathbf{d})$ & $55(\mathrm{c}+\mathrm{d})$ \\
\hline Total & $91(\mathrm{a}+\mathrm{c})$ & $14(\mathrm{~b}+\mathrm{d})$ & $\mathbf{1 0 5}$ \\
\hline
\end{tabular}

Pearson's analysis showed that there was no correlation ( $p$ 0.538) between the conjunctival impression cytology and the contrast sensitivity test.

\section{References}

1. Combs G, Fernald. The Vitamins, fundamental aspects in nutrition and health. New York: Academic Press Inc. 2000; pp. 119-248.

2. Muhilal, Kurniawan A, Sirlan SF, Harmani B, Hendarto A, Sunarko, et al. Deteksi dan tatalaksana kasus xeroftalmia. In: Kurniawan A, Sumarna E, Suroto, Wardhani RW, Trisnawati N, editors. Dep. Kes. RI 2003; p. 121.

3. Humprey JH, West KP, Sommer A. Vitamin-A deficiency and attributable mortality among under 5-year-olds. Bulletin of the World Health Organization 1992;70:225-232.

4. World Health Organization. Indicators for assessing vitamin-A deficiency and their application in monitoring and evaluating intervention programs. Geneva: World Health Organization; 1996.

5. Bellagio meeting on vitamin-A deficiency SL childhood mortality. In: Bochnovic B (Ed.), Bellagio Study and Conference Center of the Rockefeller; 1993; United States of America: Johns Hopkins University; 1993

6. Natadisastra G, Wittpenn J, West KP, Muhilal, Sommer A. Impression cytology for detection of vitamin-A deficiency. Arch Ophthalmol 1987;105:1224-1228.

7. Natadisastra G, Wittpenn J, Muhilal. Impression cytology: a practical index of vitamin A status. Ann J Clin Nutr 1988;49:695-701

8. Reddy V, Rao V, Arunjyothi, Reddy M. Conjunctival impression cytology for assessment of vitamin A status. Am J Clin Nutr 1989;50:814-817.

9. Gadomski AM, Kjolhede CL, Wittpenn J, Bulux J, Rosas AR, Forman MR. Conjunctival impression cytology $(\mathrm{CIC})$ to detect sub clinical vitamin-A deficiency; comparison of $\mathrm{CIC}$ with biochemical assessments. Am J Clin Nutr 1989;49:495-500.

10. Tseng SCG. Impression cytology histochemical method for investigating ocular surface epithelial differentiation. 2008 [cited 2008 Dec 19]; available from: http://www.ocularsurface.com.

11. Khan NC, Ninh NX, Nhien NV, Khoi NN, West CE, Hautvast JG. Sub clinical vitamin-A deficiency and anemia among Vietnamese children less than five years of age. Asia Pac J Clin Nutr 2007;16:152-157.

12. Schwartz S. Visual perception. In: Schwartz S (Ed.), A clinical orientation. Connecticut: Appleton and Lange 1994; pp. 23-60.

13. Miller D Glare. Contrast sensitivity testing. In: Tasman W, Jaeger E (Eds.), Duane's Clinical Ophthalmology. Philadelphia: Lippicott-Raven 1997; pp. 1-9.

14. Mantyjarvy M, Laitinen T. Normal values for the Pelli-Robson contrast sensitivity test. J Cataract Refract Surg 2001;27:261-266.

15. Newman N, Capone A, Leeper HF, O'Day D, Mandell B, Lambert SR, Thoft RA. Clinical and subclinical ophthalmic findings with retinol deficiency. Ophthalmol 1994;101:1077-1083. 
16. HKI. Program pemberian vitamin A menyelamatkan penglihatan dan kehidupan anak-anak Indonesia 2003 [cited 2008 Dec 13]. Available from: http://www.hellenkellerinternational.com.

17. Siagian A. Pendekatan fortifikasi pangan untuk mengatasi masalah kekurangan zat gizi mikro 2003 [cited 2008 Dec 19]. Available from: http://www.defisiensivitamina.com.

18. Sudirman H. Tantangan LitBang lintas disiplin dalam penanggulangan masalah kemiskinan, kelaparan, dan gizi kurang di Indonesia. Jakarta: Dep.Kes.RI 2008.

19. HKI. Program pemberian vitamin A menyelamatkan penglihatan dan kehidupan anak-anak Indonesia 2003 [cited 2008 Dec 13]. Available from: http://www.hellenkellerinternational.com.

20. Soebijantoro I. Pemeriksaan sensitivitas kontras sebagai indikator defisiensi vitamin A (tesis). Jakarta. Universitas Indonesia 2003.

21. Sekarsari N. Efek suplementasi vitamin A terhadap sensitivitas kontras penderita defisiensi vitamin A (tesis). Jakarta: Fakultas Kedokteran Universitas Indonesia 2004.

22. Cideciyan AV, Pugh EN Jr, Lamb TD, Huang Y, Jacobson SG. Rod plateaux during dark adaptation in Sorsby's fundus dystrophy and vitamin-A deficiency. Invest Ophthalmol Vis Sci 1997;38:1786-1794.

23. Tanchocho C, Rodriguez M, Olivar-santos E, Velandria F, Magbitang J. Relationship of conjunctival impression cytology with clinical and biochemical assessment of vitamin A status of preschoolers. Asia Pac J Nutr 1998;7:160-163.

24. Dinas Kesehahtan Kabupaten Purwakarta. Purwakarta dalam angka 2008. Purwakarta: Dinkes Purwakarta 2008; pp. 87-88.

25. Melandezio GV, Rocanda MJ, Toporovski J, Tiokani E, Son DW. Relationship between acute diarrhea and low plasma level of vitamin A and retinol binding protein. Rev Int Med 1996;38:365-369.

26. Rostami N, Farsar AR, Shiva N. Prevalence of sub clinical vitamin-A deficiency in 2-5 year old children in Tehran. East Mediterr Health J 2007;13:273-279.

27. Stephenson M. Contrast sensitivity testing in eye exams. 2008 [cited 2008 Dec 19]; available from: http://www.contrastsensitivity.com.

28. Handayani D. Efek suplementasi antioksidan pada anak-anak dengan sensitivitas kontras abnormal di Nangroe Aceh Darussalam. Tesis. Fakultas Kedokteran Universitas Indonesia Program Studi Ilmu Penyakit Mata. Jakarta 2005.

29. Morse A. Diagnostic cytopathology: specimen collection, preparation and cell appearances. In: Brancroft, Gamble M (Eds.), Theory and practice of histological techniques. Edinburgh: Churchill Livingstone 2002, pp. 621-662. 


\section{Xalatan: $\mid$ Xalacom}

\section{Efizer}

\section{One Drop a day helps them see what matters most..$^{1-4}$}

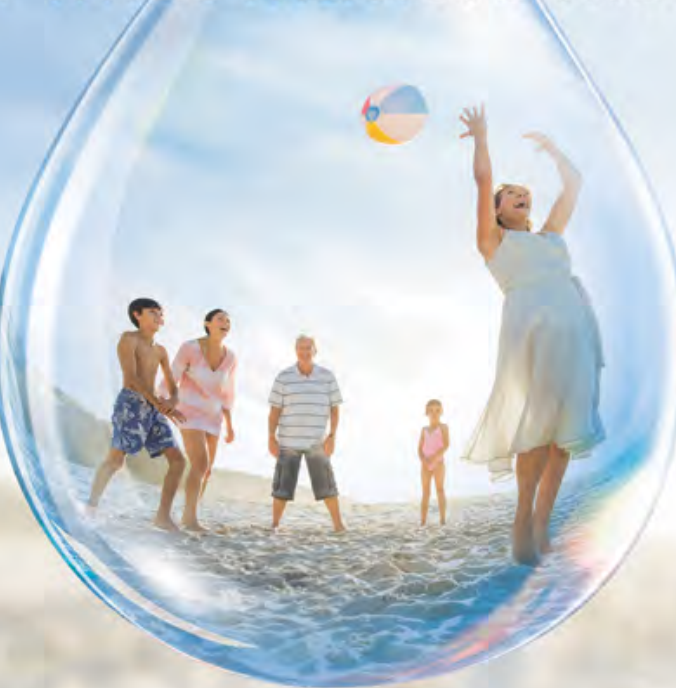

For over 10 years, Xalatan $^{\circledR}$ and Xalacom ${ }^{\circledR}$ have offered patients effective glaucoma treatments with the convenience of one bottle, one drop, once a day. ${ }^{1-4}$

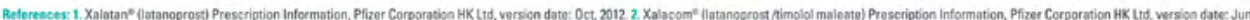

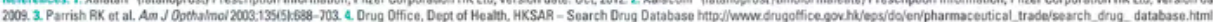

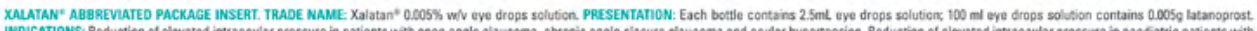

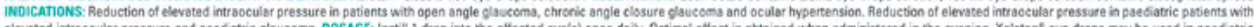

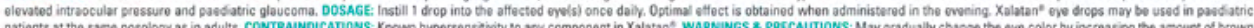
patients st the same posology as in adults. CONTRAUNOICANONS: Known hypersensitivity to any component in Xalatant. WARNiNGS \& PRECAUTIONS: May gradually change the eve color by increasing the amount of brown pigment in the inis. Patients should be monitored regularly and if the clinical situasion warrants, Xalazan" treatment may be discontinued. Xalatan* should be esed with caution in peri-operative peciod of cataract surgery patients, patients with a history of herpebic kerautis, aphakie pabents, in pseudophatic patients with torn posterior lens capsule or anterior chamber lenses, or in pubients with knowa risk factors for cystoid macular cedema, asthmatic patients. Experience to date shows that periorbital skin discolouration is not permanemt. Latanoprost may gradually champe evelashes and vellus hair in the treated eye and surrounding areas. Xalatan" contain. benzalkorium chloride. Contact lenses may sbsorb benzalkonium chloride and these should be removed before appiving Xalatan" but may be reinserted after 15 minutes. Ellicacy and safecty data in the age group < 1 year are

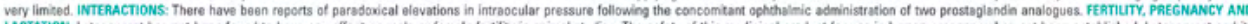
LACTarioN: Latanoprost hes not been found to have any effect on male or femele fertily in anima/ studes. The safeey of this medicinal product for use in human pregnency hes not been estabished. Latanoprost and its metabolites may pass into breast milk and Xalatan?" should therefore not be used in nutsing women of bresst feeding should be stopped. SiDE EFFECTs: Incteased iris pigmentation, mild to moderate conjunctival hyperaemila

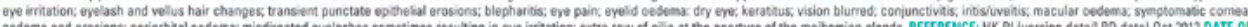

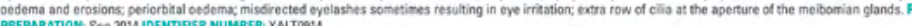

XULACOM" ABEAEVIATED PACKAGE INSERT. TRADE NAME: Xalacom" eye drops, solution 2.5mL, PRESENTATION: Each mi of Xalacom" contains 50meg latanoprost and $5 \mathrm{mg}$ timdlol. INDICATIONS: Reduction of imraoculat

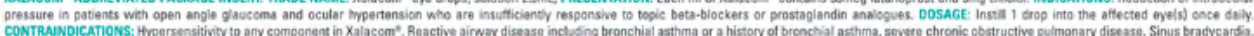

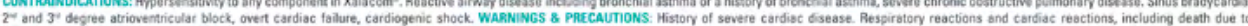

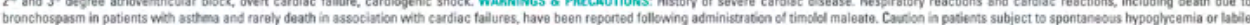

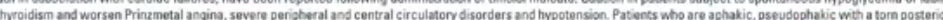
lens capsule or with known risk factors for macular oedema. Mary cause change in eve colour. Coenact lenses should be removed before asministration and mayte reinserted after 15 minutes INTERACTioNs: The use of twe

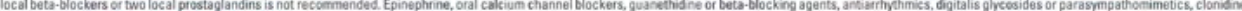

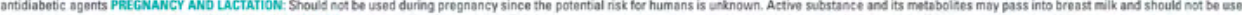

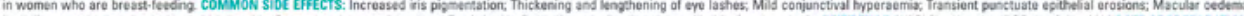

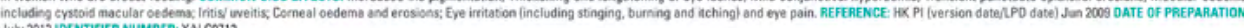
JUlY 2012 IOEENTFER NUMBBER: XALCO712

FULL PRESCRIBING INFORMATON IS AVAILABLE UPON REOUEST. 


\section{Asian Journal of}

Volume $13 \cdot$ Issue $4 \cdot 2014 \cdot 1560-2133$

www.asjoo.com www.kuglerpublications.com 